\title{
Those were the days: welfare nostalgia and the populist radical right in the Netherlands, Austria and Sweden
}

\author{
Sven Schreurs \\ Faculty of Arts, University of Groningen, Groningen, The Netherlands \\ Email: svenschreurs@gmail.com
}

(Received 13 July 2020; revised 6 October 2020; accepted 7 October 2020)

\begin{abstract}
In academia and beyond, it has become commonplace to regard populist parties - in particular, those on the radical right - as the archetypical embodiment of politics of nostalgia. Demand-side studies suggest that nostalgic sentiments motivate populist radical-right (PRR) voting and welfare chauvinist attitudes, yet systematic analyses of the nostalgic discourse that these parties promote have not been forthcoming. This paper seeks to fill that lacuna by analysing how the Freedom Party of Austria, the Dutch Party for Freedom and the Sweden Democrats framed the historical fate of the welfare state in their electoral discourse between 2008 and 2018. It demonstrates that their commitment to welfare chauvinism finds expression in a common repertoire of "welfare nostalgia," manifested in the different modes of "reaction," "conservation" and "modernisation." Giving substance to a widespread intuition about PRR nostalgia, the paper breaks ground for further research into nostalgic ideas about social policy.
\end{abstract}

Keywords: nostalgia; radical right; populism; welfare state; collective memory; welfare chauvinism

\section{Introduction}

Populist political parties and movements are often seen to embody a contemporary politics of nostalgia (Campanella \& Dassù, 2019; Kenny, 2017). Those on the radical right, in particular, are perceived as profligate consumers and fervent producers of a nostalgic language that expresses a lost sense of "place" and a longing for "home" (Duyvendak, 2011). US President Donald Trump's oft-cited promise to "make America great again" might be the most (in)famous case of the (re-)emergence of nostalgia on the political scene. In Western Europe and beyond, the rhetoric of populist radical-right parties (PRRPs) is typically predicated on ideas of lost national sovereignty, the declining moral order of society and the failure of the welfare state, as Betz and Johnson (2004, p. 311) already observed when they spoke of "the nostalgic ideology of the contemporary radical populist right."

The nostalgic rhetoric of PRRPs appears to resonate with an electorate that is predominantly white, male, older and lower-educated (Inglehart \& Norris, 2016). Indeed, a report by the think tank Demos suggests that feelings of nostalgia are shared by many voters: it found widespread societal malaise in Germany, France and Britain, not just among the most disadvantaged groups but among middle-class citizens more generally (Gaston \& Hilhorst, 2018). Rather than direct poverty, these social strata experience a relative decline in status that has prompted a "fear of falling" (cf. Ehrenreich, 1989). Recent survey-based studies confirm that a sense of "nostalgic deprivation" - a subjective manifestation of socioeconomic risk - is a major motivator behind support for PRRPs as well as welfare chauvinist attitudes (Gest et al., 2018; Kros \& Coenders, 2019; Steenvoorden \& Harteveld, 2018). 
Various authors have made casual observations about the prominent place of nostalgia in the political discourse of the populist radical right (eg Inglehart \& Norris, 2016; Mudde, 2018). Hemerijck (2013) and Elchardus (2009) recount briefly how nostalgic narratives about the lost golden age of welfare capitalism are an expression of, and a driving force behind, welfare chauvinism. Fenger (2018) has more concretely identified "welfare nostalgia" as the social policy agenda of particular PRRPs in Western Europe; yet besides his study, analyses of the makeup, usage and context-dependence of PRR nostalgia vis-à-vis the welfare state have been few and far between. We are faced with a lack of empirical investigation of, and theorising about, the types of conceptual arrangements and rhetorical strategies that PRRPs use in their nostalgic discourse. To fill that gap, this article takes stock of the supply of nostalgic frames employed by radical-right populist parties and politicians in expressing a welfare chauvinist agenda.

In this article, I analyse the nostalgic language about the welfare state and its historical trajectory among three European PRRPs which have an outspoken welfare chauvinist profile. To find out if they exhibit a common "welfare nostalgia" and (if so) which rhetorical tropes constitute this general frame, the present study examines the discourse of three PRRPs that have been identified as categorical examples of welfare chauvinism: the Sweden Democrats (SD), the Freedom Party of Austria (FPÖ) and the Dutch Party for Freedom (PVV) (Ennser-Jedenastik, 2016; Norocel, 2016; Otjes, 2019; Rathgeb, 2020). In order to identify the shared features of welfare nostalgia among these parties and map its contextual variation, the analysis concentrates on how their electoral discourse between 2008 and 2018 framed the welfare state and its history.

The following section explores the usage of the concept of (welfare) nostalgia in populism scholarship up to the present. In the subsequent conceptual framework, I elaborate on my understanding of welfare nostalgia, drawing on the broader literature on nostalgia and framing theory. I then set out the research design and present the results of the analysis. It finds that there is major convergence between the parties in their diagnostic (ie problem-defining) nostalgic frames but divergence with regard to the prognostic (ie problem-solving) framing of the welfare state. On the basis of these results, the paper identifies three ideal-typical modes of PRR welfare nostalgia: modernisation, conservation and reaction. The conclusion summarises and reflects on the analytical potential of welfare nostalgia for scholarship on the populist radical right and the politics of social policy more generally.

\section{Radical-right populism and (welfare) nostalgia: existing approaches}

In the debate on radical-right populism, it has almost become a truism to remark that PRR politicians are adept at deploying collective memory to cultivate a romantic image of the national past and mobilise their electorate (Akkerman et al., 2016; Caramani \& Manucci, 2019; Inglehart \& Norris, 2016; Wodak \& Forchtner, 2014). Despite this recognition, most authors in the field only mention nostalgia sporadically and rarely use it as an analytical lens. Explicit discussion of this nostalgic element is limited to some older classic studies. The prime example of these is Betz and Johnson's (2004, p. 324) depiction of radical-right populism as a "backward-looking reactionary ideology, reflecting a deep sense of nostalgia for the good old days." In a similar vein, but without using the exact term, Taggart (2004, p. 274) highlights the centrality of the "heartland" in populist rhetoric: "an ideal world [...] constructed retrospectively from the past [from which] populism derives what values it has."

Recent demand-side studies have reassessed the ideas of Betz, Johnson and Taggart by analysing how nostalgic sentiments influence voting behaviour and social policy attitudes. Gest et al. (2018) reveal a positive relationship between "nostalgic deprivation" - the sense of status decline due to economic and demographic change - and support for the radical right among white voters in Britain and the United States. Rooduijn and Burgoon (2018, p. 1745) also suggest that "subjective economic hardship [...] spurs support for radical right parties" in a favourable macroeconomic context. These findings confirm that "the sense of decline or feelings of relative deprivation can drive people towards populist parties" (Elchardus \& Spruyt 2016, p. 126). Along similar lines, Steenvoorden and Harteveld (2018, p. 44) identified societal pessimism as "a defining characteristic of PRR voters" and proposed that these parties "match their societal outlook and offer a solution by suggesting a return to the (idealised) past." 
The notion of welfare chauvinism also shows some affinity with nostalgia. This denotes the combined approval for (enlarged) social security for native citizens and opposition to (equal-access) welfare support for non-natives (Andersen \& Bjørklund, 1990; Greve, 2019). The concept is sometimes extended to include "welfare authoritarianism," which denies social support to undeserving natives such as the "work-shy" and welfare "cheaters" (Häusermann et al., 2013; Otjes et al., 2018). Elchardus (2009) and Hemerijck (2013) note how these attitudes are expressed in, and motivated by, a popular nostalgic narrative about the lost "golden age" of the welfare state when assistance was generous for those who worked hard and needed it. Empirical analysis of, and theorising about, this welfare (chauvinist) nostalgia has been rare, however.

The term "welfare nostalgia" has found limited usage in academic and public discourse. In the United States, it has referred negatively to a progressive yearning for the "good old days of big welfare rolls" before the Clinton administration ended "welfare as we know it" (Bailey, 2002; Marshall, 2011). In the Nordic context, the term has been used to describe a sense of loss of post-war social solidarity and political consensus (Kärkkäinen, 2019; Stougaard Nielsen, 2017). Andersson (2009) explicitly connects the wave of "Nordic nostalgia" since the mid-1990s to the breakthrough of the radical-right populist Sweden Democrats. Thomas (2011) has described the "welfare state nostalgia" of left- and right-wing populist electors in the Netherlands as "a dangerous sentiment" and an expression of "shortsightedness." In short, the concept has so far remained more of a pejorative than a well-developed analytical lens.

The exception is Fenger's (2018, p. 202) use of the concept of welfare nostalgia in his study on radicalright social policy agendas; he concluded that there "seems to be no welfare nostalgia without fierce welfare chauvinism, and opposite." By this account, however, nostalgia is not a general feature of PRRPs, but merely one type of social policy programme associated with the PVV and Flemish Interest. Their nostalgic agenda is conceived as distinct from the "social investment" programme of SD and the "modernisation" policies of the Front National and the Alternative for Germany. The reader receives no explanation as to why this nostalgia would be limited to two parties, nor - more profoundly - how it operates as a rhetorical device in PRR discourse. This is symptomatic of a general lacuna in the literature. As Kenny (2017, p. 258) observes, "very few accounts of politics, and of populism specifically, seek to probe the nature and appeal of the nostalgic." The current study seeks to contribute to filling that gap. As a starting point from which to conceptualise and analyse the welfare nostalgia of the populist radical right, the next section provides a definition of nostalgia as a political frame.

\section{Conceptual framework: nostalgia as a political frame}

While nostalgia remains an underdeveloped subject of political analysis, it has received much more consistent attention in the field of cultural studies. In the standard work of nostalgia scholarship, Boym (2002) discerns between two modalities: a "restorative" nostalgia that endeavours to realise its glorious historical vision through radical action in the present (eg fascism), and a "reflective" form that is more detached - invoking fleeting memories to create an ironic distance between now and then. As Kenny (2017, p. 263) argues, however, this dichotomy obscures the more banal manifestations of nostalgia visible in "[s] uch sentiments as the pleasures of familiarity, the comfort of tradition and feelings of reassurance" which "do not appear to promote either restorative fantasy or reflective displacement." Writing on eighteenth-century poetry, Santesso (2006, p. 39) uses the concept of "pastoral nostalgia" to denote the longing for a simpler world that has been lost - noting that it is "a naturally political genre." As we shall see, PRR welfare nostalgia generally resembles this banal, pastoral expression of nostalgia.

Following Elgenius and Rydgren (2019), nostalgia - with its potential to mobilise (protest) voters - is treated in this article as a "frame" as commonly used in the social movements literature (cf. Benford \& Snow, 2000; Snow, 2014). Frames, defined along these lines, are interpretive schemata or "discursive structures aiming to supply and make available versions of reality that cater to their producers' strategic needs in the wider struggle for social meaning making" (Aslanidis, 2018, p. 445). Insofar as it is a generic frame that is available to different political entrepreneurs across movement-specific situations, welfare nostalgia can be regarded as a "master frame" (Benford \& Snow 2000, pp. 618-619). To summarise, I 
conceive of welfare nostalgia as a potential master frame employed in PRRP discourse (although not unique to it) that strategically mobilises collective memories of the welfare state and is semantically connected to the anti-elitist, welfarist and nativist ideas that underpin welfare chauvinism. The content of a nostalgic narrative will depend on the national peculiarities of collective memory, but - based on the casual observations of myself and others - I still expect the parties to invoke similar frames that express a longing for the postwar "golden age" of the welfare state.

\section{Research design}

\section{Case selection}

To capture the welfare nostalgia of PRRPs and categorise its manifestations, this article analyses and compares the welfare-nostalgic narratives and (master) frames in the electoral discourse of three parties: the FPÖ, the PVV and the Sweden Democrats (SD). Although most contemporary PRRPs in Western Europe are committed to welfare chauvinism in some form and degree, these three parties can be seen as early adopters with a particularly outspoken welfare chauvinist profile (Akkerman et al., 2016; Norocel, 2016; Rathgeb, 2020; Schumacher \& van Kersbergen, 2016). FPÖ and PVV initially advocated the "winning formula" of authoritarian nativism and economic liberalism (Kitschelt, 1995) but moved towards strong pro-welfare positions during the 2000s - in particular after the 2008 financial crisis. Their strategy since has been "to reframe welfare state issues as immigration issues and vice versa," as Akkerman (2016, p. 149) writes with regard to the PVV. The FPÖ "rebranded itself as the 'social homeland party' [...] putting its pro-welfare self-image front and center," which according to Ennser-Jedenastik (2016, p. 416) "clearly put [it] back on the winning track." In contrast, SD originated as an extreme-right fringe movement but has attempted to establish itself as a mainstream, conservative welfarist party since the 2000s. In that process, it has used "folkhem [ie welfare state] nostalgia as a means to consolidate a coherent political platform for its welfare chauvinist agenda" (Norocel, 2016, p. 372).

Besides sharing a strong commitment to welfare chauvinism, SD, FPÖ and PVV operate in "small states in world markets" (Katzenstein, 1985). Sweden, Austria and the Netherlands combine high levels of economic openness with generous welfare provisions and a large public sector. These features are intimately connected with a shared history of democratic corporatism, based on institutionalised partnerships between state, capital and labour in socioeconomic affairs. At the same time, the countries organised their welfare state and the execution of social policy in different ways, respectively representing a social democratic, conservative-corporatist and hybrid regime (Esping-Andersen, 1990; van Oorschot, 2006). Since they reflect dissimilar trajectories in political history, such disparities could be associated with different collective memories of the welfare state and - by implication - different expressions of nostalgia.

Among these PRRPs, I nevertheless expect to encounter a common core of welfare nostalgia that is relatively indifferent to the institutional design and ideational makeup of welfare arrangements. If this hypothesis holds up and the three PRRPs indeed express a similar welfare nostalgia in their discourse, this would suggest that the welfare chauvinist agenda of the European populist radical right draws upon and reproduces - a rhetorical repertoire that transcends the political, economic and cultural environment of the nation-state within which welfarism is generally organised. Welfare nostalgia could then be considered a radical-right populist and welfare chauvinist "master frame" with transnational purchase. ${ }^{1}$ Domestic context would still shape the political opportunity structure in which PRRPs act, since "different types of social programmes [...] vary in their degree of vulnerability to welfare chauvinistic appeals" (Ennser-Jedenastik, 2018, p. 294); however, the expression of welfare nostalgia would not be determined by those institutional constraints.

\footnotetext{
${ }^{1}$ This is not meant to imply that welfare nostalgia as a master frame is unique to the political discourse of radical-right populism and welfare chauvinism. As suggested in the conclusion, it is plausible that a nostalgic understanding of the welfare state also manifests itself among parties that belong to different ideological families. However, it is unlikely that the welfare nostalgia of those parties depends on the same rhetorical tropes and strategies, even if there might be (superficial) commonalities.
} 


\section{Data and methods}

In the empirical section below, I assess in detail whether we can identify a generic frame of welfare nostalgia as expressed by welfare chauvinist PRRPs. The analysis is based on a set of electoral manifestos, speeches and campaign videos. Apart from their available quantity, these source types were chosen for their public and persuasive nature. Given that election discourse primarily serves to convince and mobilise the electorate, nostalgia is expected to be more salient than, for example, in the more professional and less visible atmosphere of parliamentary debates. The different sources are complementary in their attention to policy questions, ideological positions and collective memory, which allows a rich analysis of problem definitions and proposed solutions to the troubles of the welfare state. Party manifestos were gathered from the Manifesto Project Database (Volkens et al., 2020) while speech transcripts and videos were collected from the parties' respective websites. All translations are the author's own. The material is listed in the appendix.

The analysis is concerned with PRR discourse between 2008 and 2018. In this timeframe, three national parliamentary elections took place in Austria, Sweden and the Netherlands, which means that there is a relatively large amount of comparable material available. Furthermore, during this period, PVV (2010) and SD (2010 and 2014) experienced their breakthrough and FPÖ made its comeback (2008). These successes are not unrelated to the political upheavals that punctuated these years: the global financial crisis, the Eurozone crisis and the migration crisis, which are likely to have nourished welfare chauvinism across the EU (Marx \& Naumann, 2018; Otjes et al., 2018). At the same time, socioeconomic issues gained salience for PRRPs and their voters (Lefkofridi \& Michel, 2017; Rovny \& Polk, 2020) while mainstream parties accommodated the welfare chauvinist positions of their populist competitors (Schumacher \& van Kersbergen, 2016).

The source material is examined through qualitative content analysis. The analytical setup is derived from Mols and Jetten's (2014) study on anti-immigration frames of the collective past in PRR discourse. The first round of analysis consisted of highlighting the passages where the parties referred back to, or hinted at, the welfare state and its historical trajectory. This was assisted by a keyword search of terms related to social policy and collective memory (eg "welfare," "social," "community," "history," "past," translated accordingly). The subsequent close readings of the relevant sections served to deconstruct the rhetorical strategies which the PRRPs used to frame (the decline of) the welfare state, mobilise their audience and legitimate their policy positions. In this second stage, I used a range of questions to identify the diagnosis and prognosis in this welfare-nostalgic discourse, as well as the sub-dimensions of its rhetorical strategy. These analytical questions were inspired by Wodak's (2001, pp. 72-73) guidelines for discourse-historical analysis and can be summarised as follows:

- Diagnosis: what used to be so good about the welfare state - and what caused its problems?

(1) Appellation: which (affective) label is used to describe the past?

(2) Periodisation: when did the "golden age" of the welfare state begin and end?

(3) Evaluation: which qualities of this historical period are highlighted?

(4) Change: how is the "turnaround" of the welfare state narrated and explained?

(5) Agency: who are portrayed as protagonists and antagonists?

- Prognosis: what should we do in the present to ensure that these good times will come back?

The next section uses the findings of the content analysis to reconstruct the welfare-nostalgic discourse of FPÖ, PVV and SD. The first part sets out the rhetorical tropes that underpin their diagnostic framing of the welfare state and its history; it then moves to the prognostic frames and the differences that were found among the parties. This eventually feeds into a summary and an overview of the rhetorical strategies that underpin the welfare nostalgia of these PRRPs, in line with the analytical dimensions outlined above. 


\section{Findings}

\section{The welfare-nostalgic diagnosis}

At first sight, the discourse of neither party qualifies as restorative nostalgia - ie a determination to break radically with the present and return to the past. There is a shared impression among the parties that there is hope for the future. As PVV leader Geert Wilders declared in his 2010 election manifesto, "we still believe that the most beautiful days of the Netherlands lie ahead of us" (PVV, 2010a). At the same time, there are recurrent indications of banal or pastoral nostalgia - a sentiment of lost tradition, certainty and simplicity - in the texts under analysis. This sense of nostalgia is expressed through the nearly ubiquitous frame that life in the Netherlands, Sweden and Austria has changed for the worse in recent decades, not least when it comes to collective welfare provision. When we trace the PRR diagnosis of the welfare state and its history, a nostalgic narrative with a number of common features emerges.

In this nostalgic view, the decades after the end of World War II - usually not defined more precisely represent the glory days of the welfare state. These are understood as a time of social cohesion and reciprocity when citizens trusted and looked after one another out of a sense of "neighbourly love," as the title of the 2013 FPÖ manifesto (Liebe deine Nächsten) suggests (FPÖ, 2013a). Through hard work and cooperation, these postwar societies achieved "a welfare and a solidarity that did not know its equal" (PVV, 2010a). This supposedly made it possible to set up extensive programmes of social assistance for the (deserving) needy: the working poor, the elderly, the disabled, the sick and the unjustly unemployed. As might be expected of banal nostalgia, the trope of a historically strong social safety net is rarely elaborate enough to identify concrete policies. Among the three parties, the political discourse of SD is most explicit in its nostalgia for the "solidaristic" past, relying heavily on the powerful myth of the folkhem or "people's home" (cf. Bergmann, 2017; Norocel, 2016). This concept is used to convey the hope that, as party leader Jimmie Åkesson put it in a 2017 speech, "class conflict and fragmentation are abandoned - in mutual agreement - in favour of [...] the community that is necessary for every human being" (SD, 2017). A similar sentiment is conveyed by the FPÖ's imagery of the "social homeland." This sense of historical community is at the core of PRR welfare nostalgia.

However, nostalgia only sets in with the feeling that one has lost something dear; the good old days must somehow have ended. Again, the exact dating of this historical change is rarely specified but the parties seem to identify it with the last quarter of the twentieth century. This would coincide with the "silent revolution" in cultural values, the backlash against which has formed an important motivation behind support for the populist radical right (Inglehart \& Norris, 2016). In the examined discourse, this turnaround is primarily portrayed as a crisis of political will rather than the result of societal change. It is alleged that the "caste" of politicians betrayed the socioeconomic needs of the native people in favour of their own narrow interests, as well as those of immigrants and "Eurocrats."

In general, the PRRPs fault the political mainstream en bloc for this historical development. As Åkesson deplored, the established parties "promise a lot of things, from left to right. But these promises not seldom lack real substance. They mean nothing" (SD, 2014). Special blame is reserved, however, for the representatives of social democracy. All parties explicitly recognise and praise the contribution of social democratic prime ministers - Willem Drees, Bruno Kreisky, Per Albin Hansson - to the creation of the welfare state. Their ambition to emancipate the lower classes is presented as a mission driven by patriotism, which has allegedly been lost on present-day social-democratic career politicians. The latter, so the PRR narrative goes, are nothing more than an ideologically indiscernible component of the "leftwing elite" (PVV) or "left-liberals" (SD) who prioritise multiculturalism and European integration over the well-being of "our own people."

The other prime actors who attract blame for the retrenchment of the welfare state are the European Union and migrants. The deepening of European cooperation is typically presented as an ever-increasing "waste of money" that ought to have been spent on domestic welfare. Moreover, especially in the context of the Eurozone crisis, "Brussels" is reproached for its strict rules that put limits on a sovereign fiscal agenda. "Foreigners" are condemned even more strongly for their negative impact on the fate of the welfare state. They are accused of making too small a contribution to the economy whilst enjoying many 
social benefits, making the costs of the welfare system unsustainable. At its heart, the nostalgic diagnosis of PVV, SD and FPÖ rests upon the welfare chauvinist dichotomy: politicians have to make a choice for either welfare or immigration, which are mutually exclusive. Over the last decades, this dilemma is seen to have been resolved in the wrong way. "Especially in the recent past, the welfare state has reached the limits of its capacity due to waves of immigration," the 2017 FPÖ manifesto notes (FPÖ, 2017a). But, as in an act of political defiance, the title of the 2014 SD manifesto declares, "we choose welfare!" (SD, 2014).

At the opposite side of the spectrum of blame in PRR welfare nostalgia, the parties place the elderly, whom they often describe as the "reconstruction generation." This group is assigned two crucial roles in the nostalgic narrative: it serves both as a historical protagonist - in the heroic position of having built up their country and the continent from the ruins of war, thus heralding the heyday of national welfarism and as the foremost victim duped by the political establishment. In the latter role, this generation is typically equated with the broader category of "pensioners." They feature, for example, in the 2018 SD manifesto as the persons "who have built Sweden and made it into a fantastic country to live in," yet whose situation has deteriorated due to the political elite's mismanagement of migration and economic policy (SD, 2018a). In a similar vein, the 2017 FPÖ election programme deplores that "over the last ten years, especially for our seniors, who built Austria up again, life has become markedly more expensive" (FPÖ, 2017a). Next to the elderly, other socially disadvantaged groups also play a role in this nostalgic discourse. They figure not as heroes, though, but only as the victims of the policies implemented by the "progressive elites."

In response to the perceived decline in the quality of life, the PRRPs advocate a response that has elements of both nostalgia and anti-nostalgia. Overall, their focus is aimed at bringing back the solidaristic community of the past through a nativist and populist political agenda, once again putting "the people" and their welfare front and centre. This would allegedly require significantly reduced levels of (if not an end to) immigration as well as a sense of national pride and unity. In 2017 Åkesson called for "mutual understanding and community in times of fragmentation and polarisation" (SD, 2017). On the economic level, the parties do not only express their wish to bring back the old level of social support that is for native citizens - but also call repeatedly for a rebalancing of rights and duties, most saliently expressed in the notion that "work should pay off" again. In these matters of immigration, citizenship, welfare and work, nostalgia appears in its most restorative form, in the sense that it suggests that a return to the cultural and socioeconomic circumstances of the postwar decades is both feasible and desirable.

It must be noted, however, that these restorative ambitions are equivocal across the board. What partially makes this nostalgic call for action more ambiguous is its pairing with an anti-nostalgic rhetoric. As indicated above, the parties are explicit about their forward-looking attitude, time and again distancing themselves from the politics of the past. "Those who choose to vote for the Sweden Democrats have understood how the old parties have abused their power and have understood how they have destroyed our country," Åkesson proclaimed in a 2018 speech (SD, 2018b). This quotation serves as a convenient illustration of Kenny's (2017, pp. 261-262) observation "that anti-nostalgia and nostalgic sentiments can be powerfully intertwined." In effect, the wish to rehabilitate the welfare regime of yore gives legitimacy to radically new political experiments. This desire to do away with the "old politics" of domestic and European elites is also evident in the ambition to reform various social policy fields healthcare and social care, unemployment insurance, pensions - in order to meet the challenges of the future. At the same time, the parties diverge markedly in the ways in which they present and legitimise such reform plans. These and related differences between the parties are the subject of the next section.

\section{Varieties of welfare nostalgia: from diagnosis to prognosis}

Given that every political community has its assemblage of collective memories through which citizens remember the past, there will be differences in the content of the nostalgic frames and tropes which political parties deploy in public discourse. Thus, the PRRPs examined in this paper invoke different collective imaginaries - the Swedish "people's home," the Austrian "social homeland," the "caring state" 
and "father Drees" in the Netherlands - that are embedded in wider discourses about national history. In part, these nostalgic images reflect divergent experiences of welfare state creation, World War II and postwar reconstruction. This explains why the welfare-nostalgic narrative of SD occasionally refers back to the 1930s, while those of PVV and FPÖ only relate to the period from 1945 onwards. Nonetheless, their nostalgic diagnosis relies on comparable sentiments and provides an analogous framing of the welfare past.

In contrast, the prognostic dimension of the parties' welfare nostalgia is marked by substantial differences. Their relatively similar understanding of welfare state history translates into different nostalgic political agendas. In other words, while the parties concur on the definition and analysis of the problem the creation and decline of the welfare state - they are at odds about its solution: how can the "welfare paradise lost" be recreated for current and future generations? I identify three diverging ways in which the PRRPs frame the connection of the past to the present and the future in their electoral discourse. These variants of nostalgic prognosis are labelled "modernisation," "conservation" and "reaction."

The concept of nostalgic modernisation is borrowed from Kalinin (2011), who introduced it to characterise the deployment of Soviet nostalgia by political elites in contemporary Russia. This apparent paradox expresses the notion that

both the nostalgic feeling and the modernizing drive are derived from the sharp division between past and present. The difference lies in nostalgia's basis in the recognition of an already existing break and its resolution of the contrast between past and present in favour of the former. By contrast, modernization is less about acknowledgement of a given break than about the assertion of its necessity. The modernizer is equally dissatisfied with the past and the present, which he perceives as a returning past. The curious characteristic of today's modernization project lies in its effort to keep the break between past and present purely within the sphere of technologies and administrative structures [while] the Soviet past [...] remains a major and immediate source of the social and psychological mobilizing energy necessary to start the engine of modernization (Kalinin, 2011, p. 162).

Briefly put, nostalgic modernisation refers to a pragmatic reconciliation between nostalgia and the drive to modernise: the idea that the further progress of the nation is dependent on adjusting its institutional arrangements to the (material) demands of the current age, while the past achievements and ideological ambitions of earlier generations are retained as a continuous source of inspiration. This sort of framing is most visible in the discourse of the Sweden Democrats. In its manifestos and the speeches of party leader Åkesson, there are recurrent calls for a modern and modernised people's home. To that end, the party proposes introducing various reforms that would overhaul the technical and administrative organisation of the welfare state. This includes allowing the private delivery of health and social care, partial relaxation of employment protection, reform of the employment services and many other (relatively detailed) policy initiatives.

In view of these policy proposals, it is understandable why Fenger (2018, pp. 203-204) categorised the social programme of SD as an agenda of "social investment" rather than "welfare nostalgia." Nevertheless, its commitment to social investment and modernisation does not offset its penchant for nostalgia. Time and again, the party clarifies that the ultimate purpose of these reforms is to safeguard the spirit of solidarity and community among (native) Swedes. As Åkesson affirmed in 2017, in the "modern people's home we dare to be proud of our history, proud of our culture, proud of what has been created and cultivated here in generations" (SD, 2017). A year later, he conveyed a similar message: "through Swedish aspiration, we recreate a safe and cohesive Sweden. A modern people's home, on the basis of freedom and community" (SD, 2018b). Thus, nostalgia and modernisation are fused into one political frame.

By comparison, the PVV's nostalgic welfare agenda is framed from a more exclusively retrospective vantage point. It puts little - if any - emphasis on policy reform, and concentrates on the maintenance of social provisions in their "original" form. The keyword in its discourse is behoud ("preservation"), that is preventing the further deterioration of the welfare state. As the 2010 electoral programme underlined, this meant that there would be no changes to "unemployment insurance, no relaxation of termination 
law, the public transport card and student grants remain in place [...] no increase in deductible excess in health care and the retirement age remains 65 years" (PVV, 2010a). Its 2017 manifesto contained even fewer social policy proposals, apart from the abolition of health insurance deductibles, a return to retirement at 65, and a reversal of austerity in the care sector (PVV, 2017a). These plans are not elaborated upon, but it is significant that they appear under the header of Nederland weer van ons! ("the Netherlands ours again”). The welfare nostalgia in the PVV's discourse, then, legitimates not just the retention of social policy as is but a return to how it used to be - or, more accurately, as it is perceived and portrayed to once have been. The tension between past and present is ultimately resolved in favour of the former; in this respect, the prognostic framing in the PVV's welfare discourse approximates Boym's ideal-type of restorative nostalgia. I classify this manifestation of welfare nostalgia as "nostalgic reaction."

The nostalgic orientation of the FPÖ is more ambiguous than that of SD and PVV, taking somewhat of a middle position. Its 2017 economic programme contains repeated calls for the modernisation of the Austrian economy - including a "modern infrastructure" and "modern [i.e. less progressive] tax policy" (FPÖ, 2017b) - but these demands make no references to the party's nostalgic vision of the welfare state. With respect to welfare issues, the FPÖ's stance is more equivocal than that of the PVV: while it emphasises the preservation or expansion of social provisions such as pensions and family allowances, it less explicit about its desire to return to the past. It appears to suggest that the best way of preserving the historical spirit of the welfare state is to keep things (mostly) as they are. The 2013 party manifesto condemns the fact that the "distribution of burdens and benefits is unfair: the masses are charged; from the needy, money is taken away and cut back" (FPÖ, 2013a) but does not mention any solutions other than the expansion of family allowances. More generally, its discourse does not indicate the need for social policy reform - other than that "those who can help themselves, but do not want to do so" should be excluded from the welfare state's reach (FPÖ, 2013a). Because the FPÖ's prognosis of welfare policy is fixated on the present and does not highlight the tensions with either the past or the future, this frame type is designated as "nostalgic conservation" (Table 1).

Overall, there appears to be no direct connection between the welfare regimes in which PRRPs operate and the described variation in nostalgic prognoses. The Sweden Democrats, who rely strongly on collective memories of the social-democratic welfare state - epitomised by the notion of the "people's home" - in fact, have the most outspoken preference for reform and retrenchment. In the context of the Dutch hybrid welfare state, and more equivocally in the conservative-corporatist Austrian regime, PVV and FPÖ refrain from advocating an overhaul of the social system or even argue for a policy reversal. As is hardly surprising, the institutional design of the welfare state and its policy technicalities play a negligible role in PRR nostalgia for the postwar era. Much more salient in their discourse are the sentimental values and principles that are seen to have buttressed the welfare state: community and solidarity among the vaguely defined (yet clearly restricted) deserving inhabitants of the nation-state.

Table 1. Overview of welfare nostalgia features.

\begin{tabular}{llll} 
& PVV & FPÖ & SD \\
\hline Appellation & The "caring state" & The "social homeland" & The "people's home" \\
\hline Periodisation & ca. 1945-1975 & ca. 1945-1975 & ca. 1930-1975 \\
\hline Evaluation & $\begin{array}{l}\text { National community and } \\
\text { solidarity }\end{array}$ & $\begin{array}{c}\text { National community and } \\
\text { solidarity }\end{array}$ & $\begin{array}{l}\text { National community and } \\
\text { solidarity }\end{array}$ \\
\hline Change & Since ca. 1975 & Since ca. 1975 & Since ca. 1975 \\
\hline Protagonists & $\begin{array}{l}\text { Willem Drees; older } \\
\text { generations }\end{array}$ & $\begin{array}{l}\text { Bruno Kreisky; older } \\
\text { generations }\end{array}$ & $\begin{array}{l}\text { Per Albin Hansson; older } \\
\text { generations }\end{array}$ \\
\hline Antagonists & Left-wing elite; migrants; EU & SPÖ-ÖVP cartel; migrants; EU & Left-liberals; migrants; EU \\
\hline Prescription & Reaction & Conservation & Modernisation \\
\hline
\end{tabular}


To my mind, a more convincing explanation for the different nostalgic orientations of these PRRPs lies in their specific profiles and the political cultures, rather than the economic-institutional structures, in which they participate. There appears to be a link between a party's nostalgic prognosis and its position in the domestic political landscape. Over the last decade, SD has made significant efforts to normalise itself politically, emphasizing its self-perception as a "social-conservative party with a nationalist ethos" (SD, 2011) to distance itself from its neo-Nazi roots. Even as it remains in opposition to national politics, the cordon sanitaire against the party has been weakened (Backlund, 2016; Jungar, 2016). This gradual normalisation cannot be understood in isolation from its commitment to a (nostalgic) modernisation of the social system, through which SD has attempted to establish itself as an affiliate of the bloc of centreright parties (Wingborg, 2016).

The PVV, in contrast, has paid scant attention to (social) policy formulation in recent years. In 2012, it withdrew its support from the right-of-centre coalition government it had tolerated after the 2010 elections over austerity measures that included cuts to state pensions and other provisions. The party has since (once again) operated at the margins of Dutch politics: it "has become more isolated politically and the goal of office-seeking has been moved further from sight" (Akkerman, 2016, p. 163). A similar dynamic affected the FPÖ, whose government stint in the early 2000 s proved internally divisive and electorally harmful. After the departure of a group of policy-seeking moderates from the party, it sought to engineer a comeback by restyling itself as the social homeland party (Heinisch \& Hauser, 2016). This translated into a nostalgic-conservative welfare agenda, the main objective of which was to oppose retrenchment for the deserving population. Following the 2017 elections, the FPÖ again entered government; it left in 2019, mired by scandal. It remains to be seen how this development has influenced its nostalgic diagnosis and prognosis of the welfare state.

\section{Discussion and conclusion}

An emerging body of research suggests that sentiments of nostalgia and status loss motivate voters to put their weight behind right-wing populist and welfare chauvinist parties. These findings allow us to establish a bridge between socioeconomic and sociocultural explanations of the rise of radical-right populism (Mudde \& Rovira Kaltwasser, 2018). Nevertheless, scrutiny of the nostalgic ideas supplied by the same parties has remained wanting. The analysis in this paper demonstrates that PRRPs in Sweden, Austria and the Netherlands resort to a similar repertoire of "welfare nostalgia" when they convey their welfare chauvinist agenda to the electorate. In view of its recurrent rhetorical features, this nostalgia can be thought of as a "master frame" that political actors invoke in different (national) contexts to persuade and mobilise their audience. This nostalgic framing of the welfare state is intimately connected to an ethno-culturalist conception of the nation; as the literature on welfare chauvinism would lead us to expect, generous welfare provision for select citizens and restrictive immigration policy are two sides of the same coin for the populist radical right.

The present study has set out in detail the elements of this welfare-nostalgic master frame. First, this nostalgia looks back at the "good old days" or "golden years" of the welfare state. The duration of this historical period is rarely identified, but it is implicitly associated with the three decades that followed World War II. In particular, the PRRPs portray the hard-working "reconstruction generation" as those who enabled the creation of the welfare state. They were able to do so under the guidance of socialminded and patriotic politicians who worked in the spirit of solidarity and national community - above all the renowned prime ministers of a social democratic persuasion (ie Drees, Kreisky, Hanson). However, this welfare paradise was supposedly lost with the gradual revolution in cultural values from the 1970s onwards. As per the nostalgic narrative, this was primarily an instance of political opportunism: progressive elites betrayed their working- and middle-class base by choosing immigration and European integration over the material and spiritual welfare of the people. Thus, the political class (and social democrats in particular) stands accused of having let down pensioners, the ill, the unemployed and other needy natives as well as the nation as a whole. 
An important caveat is that while the Sweden Democrats, the Freedom Party of Austria and the Dutch Freedom Party share a welfare-nostalgic diagnosis, they provide different prognoses about the future of the welfare state. SD is forthright about its intentions to modernise the arrangements of Swedish welfare provision so as to realise its nostalgic vision of the people's home. I classify this pragmatic reconciliation between nostalgia and future-oriented policies as "nostalgic modernisation." In contrast, FPÖ and PVV barely flag that they intend to update contemporary welfare institutions. The "nostalgic reaction" of the PVV seeks to restore the Dutch "caring state" in its supposed original historical form, while the FPÖ's "nostalgic conservation" puts emphasis on the preservation of the Austrian "social homeland" as it presently exists.

These different modes of nostalgia do not seem to correspond with the institutional variation in welfare regimes. The difference rather appears to reflect the ways in which the PRRPs position themselves in the domestic political landscape. Whereas SD has expressly sought to enter the political mainstream since at least 2010, PVV and FPÖ radicalised after the disappointing experience of being a (supporting) party of government. Otjes et al. (2018) suggest that this difference is mirrored in socioeconomic policy positions, which in the case of SD have consistently been less populist, authoritarian and nativist than FPÖ and PVV. The constructive, reform-oriented welfare nostalgia of SD would make it considerably easier to present itself as a coalition partner for the right-wing parties in parliament.

In short, the fact that a party is nostalgic about the welfare state tells us little about its policy commitments. It might advocate far-reaching modernisation or voice support for a reversal of the changes that have occurred over the last decades. In this respect, it is important to underline what earlier analyses of radical-right populism and welfare chauvinism have overlooked or underplayed. Pace Fenger (2018), we should not understand welfare nostalgia as a distinct social policy agenda but rather as a common discursive repertoire on which PRRPs draw when they express their commitment to welfare chauvinism. It is plausible that this nostalgic rhetoric appeals to the disaffected, lower educated, working- and lowermiddle-class white electorate among which most European PRRPs have a strong foothold (Afonso, 2015; Arzheimer, 2012; Oskarson \& Demker, 2015). Promises of a return to the "good old days" might resonate with an existing sense of relative deprivation while reinforcing that sentiment at the same time.

Welfare nostalgia is unlikely to be unique to the populist radical right, however. Even if its nostalgia can be seen as particularly conspicuous, the political mainstream and left-wing challengers may equally rely on a romantic understanding of the past (cf. Jobson \& Wickham-Jones, 2010; Kenny, 2017). In that light, further comparison of nostalgic social policy narratives would prove insightful. At the same time, we should not forget the demand side of nostalgia. Despite the recent wave of scholarship on nostalgic deprivation and societal pessimism, we still know little about the ways in which citizens envisage the past and react to the nostalgic language of politicians - for example, how does the welfare nostalgia of PRRPs resonate with various sections of the electorate? As a case in point, Kenny's (2017) study of Enoch Powell illustrates how audiences can interpret the nostalgia of a national-populist political entrepreneur differently than intended. Although methodologically challenging, it could be fruitful to further examine the production and reception of (welfare) nostalgia in populist and anti-populist politics.

Acknowledgements. The author is grateful to Stefan Couperus for his invaluable comments on earlier drafts of this article. He would also like to thank two anonymous reviewers for their useful remarks.

Sven Schreurs is a research master student of Modern History and International Relations at the University of Groningen. His research interests relate to EU politics, radical-right populism, social democracy and the role of ideas in policymaking.

\section{References}

Afonso, A. (2015). Choosing whom to betray: Populist right-wing parties, welfare state reforms and the trade-off between office and votes. European Political Science Review, 7(2), 271-292.

Akkerman, T. (2016). The Party for Freedom: Balancing between mission, votes and office. In T. Akkerman, S. L. de Lange, \& M. Rooduijn (Eds.), Radical right-wing populist parties in Western Europe: Into the mainstream? (pp. 144-168). London: Routledge. 
Andersen, J. G., \& Bjørklund, T. (1990). Structural changes and new cleavages: The progress parties in Denmark and Norway. Acta Sociologica, 33(3), 195-217.

Andersson, J. (2009). Nordic nostalgia and Nordic light: The Swedish model as Utopia 1930-2007. Scandinavian Journal of History, 34(3), 229-245.

Arzheimer, K. (2012). Working Class Parties 2.0? Competition between centre left and extreme right parties. In J. Rydgren (Ed.), Class politics and the radical right (pp. 75-90). London: Routledge.

Aslanidis, P. (2018). Populism as a collective action master frame for transnational mobilization. Sociological Forum, 33(2), 443-464.

Backlund, A. (2016). Isolation and policy co-optation: The path dependency of the Swedish Cordon sanitaire. Swedish political science association conference paper, Visby.

Bailey, R. (2002). Welfare nostalgia. Reason, 29 July, https://reason.com/2002/07/29/welfare-nostalgia/.

Benford, R. D., \& Snow, D. A. (2000). Framing processes and social movements: An overview and assessment. Annual Review of Sociology, 26, 611-639.

Bergmann, E. (2017). Nordic nationalism and right-wing populist politics: Imperial relationships and national sentiments. London: Palgrave Macmillan.

Betz, H.-G., \& Johnson, C. (2004). Against the current - stemming the tide: The nostalgic ideology of the contemporary radical populist right. Journal of Political Ideologies, 9(3), 311-327.

Boym, S. (2002). The future of nostalgia. London: Basic.

Campanella, E., \& Dassù, M. (2019). The age of nostalgia. Foreign Policy, 14 May.

Caramani, D., \& Manucci, L. (2019). National past and populism: The re-elaboration of fascism and its impact on right-wing populism in Western Europe. West European Politics, 42(6), 1159-1187.

Duyvendak, J.-W. (2011). The politics of home: Belonging and nostalgia in Europe and the United States. London: Palgrave Macmillan.

Ehrenreich, B. (1989). Fear of falling: The inner life of the middle class. New York: Pantheon.

Elchardus, M. (2009). Social discontent in European welfare states. In A. Hemerijck, B. Knapen, \& E. van Doorne (Eds.), Aftershocks: Economic crisis and institutional choice (pp. 145-154). Amsterdam: Amsterdam University Press.

Elchardus, M., \& Spruyt, B. (2016). Populism, persistent republicanism and declinism: An empirical analysis of populism as a thin ideology. Government and Opposition, 51(1), 111-133.

Elgenius, G., \& Rydgren, J. (2019). Frames of nostalgia and belonging: The resurgence of ethno-nationalism in Sweden. European Societies, 21(4), 583-602.

Ennser-Jedenastik, L. (2016). A welfare state for whom? A group-based account of the Austrian Freedom Party's social policy profile. Swiss Political Science Review, 22(3), 409-427.

Ennser-Jedenastik, L. (2018). Welfare chauvinism in populist radical right platforms: The role of redistributive justice principles. Social Policy \& Administration, 52(1), 293-314.

Esping-Andersen, G. (1990). The three worlds of welfare capitalism. Princeton: Princeton University Press.

Fenger, M. (2018). The social policy agendas of populist radical right parties in comparative perspective. Journal of International and Comparative Social Policy, 34(3), 188-209.

Gaston, S., \& Hilhorst, S. (2018). At home in one's past: Nostalgia as a cultural and political force in Britain, France and Germany. London: Demos.

Gest, J., Reny, T., \& Mayer, J. (2018). Roots of the radical right: Nostalgic deprivation in the United States and Britain. Comparative Political Studies, 51(13), 1694-1719.

Greve, B. (2019). Welfare, populism and welfare chauvinism. Bristol: Bristol University Press.

Haüsermann, S., Picot G., \& Geering, D. (2013). Review article: Rethinking party politics and the welfare state - recent advances in the literature. British Journal of Political Science, 43(1), 221-240.

Heinisch, R., \& Hauser, K. (2016). The mainstreaming of the Austrian Freedom Party: The more things change. In T. Akkerman, S. L. de Lange, \& M. Rooduijn (Eds.), Radical right-wing populist parties in Western Europe: Into the mainstream? (pp. 73-93). London: Routledge.

Hemerijck, A. (2013). Changing welfare states. Oxford: Oxford University Press.

Inglehart, R., \& Norris, P. (2016). Trump, Brexit, and the rise of populism: Economic have-nots and cultural backlash. HKS Faculty Research Working Paper, Harvard Kennedy School.

Jobson, R., and Wickham-Jones, M. (2010). Gripped by the past: Nostalgia and the 2010 labour party leadership contest. British Politics, 5(4), 525-548.

Jungar, A.-C. (2016). The Sweden democrats. In R. Heinisch \& O. Mazzoleni (Eds.), Understanding populist party organisation (pp. 189-220). London: Palgrave.

Kalinin, I. (2011). Nostalgic modernization: The Soviet past as "historical horizon". Slavonica, 17(2), $156-166$.

Kärkkäinen, C. (2019). Släpp välfärdsnostalgin. Svenska Dagbladet, 12 June.

Katzenstein, P. J. (1985). Small states in world markets: Industrial policy in Europe. Ithaca: Cornell University Press.

Kenny, M. (2017). Back to the populist future? Understanding nostalgia in contemporary ideological discourse. Journal of Political Ideologies, 22(3), 256-273. 
Kitschelt, H. (1995). The radical right in Western Europe: A comparative analysis. Ann Arbor: University of Michigan Press.

Kros, M., \& Coenders, M. (2019). Explaining differences in welfare chauvinism between and within individuals over time: The role of subjective and objective economic risk, economic egalitarianism, and ethnic threat. European Sociological Review, 35 (6), 860-873.

Lefkofridi, Z., \& Michel, E. (2017). The electoral politics of solidarity. The welfare state agendas of radical right parties. In K. Banting \& W. Kymlicka (Eds.), The strains of commitment: The political sources of solidarity in diverse societies (pp. 233-267). Oxford: Oxford University Press.

Marshall, W. (2011). Welfare nostalgia won't help poor. Huffington Post, 30 August, https://www.huffpost.com/entry/welfarenostalgia-wont-help_b_937798.

Marx, P., \& Naumann, E. (2018). Do right-wing parties foster welfare chauvinistic attitudes? A longitudinal study of the 2015 "refugee crisis" in Germany. Electoral Studies, 52, 111-116.

Mols, F., \& Jetten, J. (2014). No guts, no glory: How framing the collective past paves the way for anti-immigrant sentiment. International Journal of Intercultural Relations, 43, 74-86.

Mudde, C. (2018). The politics of nostalgia. In The far right in America (pp. 108-110). Abingdon: Routledge.

Mudde, C., \& Rovira Kaltwasser, C. (2018). Studying populism in comparative perspective: Reflections on the contemporary and future research agenda. Comparative Political Studies, 51(13), 1667-1693.

Norocel, O. C. (2016). Populist radical right protectors of the Folkhem: Welfare chauvinism in Sweden. Critical Social Policy, 36 (3), 371-390.

Oskarson, M., \& Demker, M. (2015). Room for realignment: The working-class sympathy for Sweden democrats. Government and Opposition, 50(4), 629-651.

Otjes, S. (2019). What is left of the radical right? The economic agenda of the Dutch Freedom Party 2006-2017. Politics of the Low Countries, 1(2), 81-102.

Otjes, S., Ivaldi, G., Jupskås, A.R., \& Mazzoleni, O. (2018). It's not economic interventionism, stupid! Reassessing the political economy of radical right-wing populist parties. Swiss Political Science Review, 24(3), 270-290.

Rathgeb, P. (2020). Makers against takers: The socio-economic ideology and policy of the Austrian Freedom Party. West European Politics, early access, https://doi.org/10.1080/01402382.2020.1720400.

Rooduijn, M., \& Burgoon, B. (2018). The paradox of wellbeing: Do unfavorable socioeconomic and sociocultural contexts deepen or dampen radical left and right voting among the less well-off? Comparative Political Studies 51(3), 1720-1753.

Rovny, J., \& Polk, J. (2020). Still blurry? Economic salience, position and voting for radical right parties in Western Europe. European Journal of Political Research 59(2), 248-268.

Santesso, A. (2006). A careful longing: The poetics and problems of nostalgia. Newark: University of Delaware Press.

Schumacher, G., \& van Kersbergen, K. (2016). Do mainstream parties adapt to the welfare chauvinism of populist parties? Party Politics, 22(3), 300-312.

Snow, D. A. (2014). Framing processes, ideology, and discursive fields. In D. A. Snow, S. A. Soule, \& H. Kriesi (Eds.), The Blackwell companion to social movements (pp. 380-412). Malden: Blackwell.

Steenvoorden, E., \& Harteveld, E. (2018). The appeal of nostalgia: The influence of societal pessimism on support for populist right parties. West European Politics, 41(1), 28-52.

Stougaard-Nielsen, J. (2017). Scandinavian crime fiction. London: Bloomsbury.

Taggart, P. (2004). Populism and representative politics in contemporary Europe. Journal of Political Ideologies, 9(3), 269-288.

Thomas, C. (2011). Verzorgingsstaatnostalgie. De Groene Amsterdammer, 11 May.

van Oorschot, W. (2006). The Dutch welfare state: Recent trends and challenges in historical perspective. European Journal of Social Securit, 8(1), 57-76.

Volkens, A., Burst, T., Krause, W., Lehmann, P., Matthieß, T., Merz, N., Regel, S., Weßels, B., \& Zehnter, L. (2020). The manifesto data collection. Manifesto project (MRG/CMP/MARPOR). Version 2020a. Berlin: Wissenschaftszentrum Berlin für Sozialforschung (WZB). https://doi.org/10.25522/manifesto.mpds.2020a.

Wingborg, M. (2016). Den blåbruna röran - SD:s flirt med Alliansen och högerns vägval. Stockholm: Leopold.

Wodak, R. (2001). The discourse-historical approach. In R. Wodak \& M. Meyer (Eds.), Methods of critical discourse analysis (pp. 63-94). London: SAGE.

Wodak, R., \& Forchtner, B. (2014). Embattled Vienna 1683/2010: Right-wing populism, collective memory and the fictionalisation of politics. Visual Communication 13(2), 231-255. 


\section{Appendix: Primary source material}

\section{Party for Freedom (PVV)}

Jansen, Paul (2009). “Wilders zweert bij aow op 65”, Telegraaf, 5 September.

Kieskamp, Wilma (2017). "Vroeger was de zorg nog goed geregeld, zeggen PVV en SP”, Trouw, 10 February.

PVV (2010a). De agenda van hoop en optimisme. Een tijd om te kiezen: PVV 2010-2015. The Hague: PVV.

PVV (2010b). "Speech Geert Wilders: PVV presenteert kandidaten,” 26 April, https://www.pvv.nl/index.php/component/ content/article/12-spreekteksten/2856-speech-geert-wilders-pvv-presenteert-kandidaten.

PVV (2012a) Hún Brussel, óns Nederland: Verkiezingsprogramma 2012-2017. The Hague: PVV.

PVV (2012b). “Spreektekst Geert Wilders: Verantwoordingsdebat 2012”, 24 May, https://www.pvv.nl/nieuwsbrief/55-nieuws brief/edities/6236-spreekteksten-geert-wilders-esm-verdrag-a-verantwoordingsdag-2012.html.

PVV (2012c). "PVV Verkiezingsfilm TK 2012”, Youtube video, 2:55, 16 July, https://www. youtube.com/watch?v=O2n3uQ purTE.

PVV (2017a). Nederland weer van ons! Verkiezingsprogramma PVV 2017-2021. The Hague: PVV.

PVV (2017b). "Speech Geert Wilders op het ENF-congres in Koblenz,” Youtube video, 22:46, 21 January, https://www.youtube. $\mathrm{com} /$ watch? $\mathrm{v}=\mathrm{VclCCUx} 3 \mathrm{vP} 8$.

\section{Sweden Democrats (SD)}

SD (2010). 99 förslag för ett bättre Sverige: Sverigedemokraternas kontrakt med väljarna 2010-2014. Stockholm: SD.

SD (2011). Sverigedemokraternas principprogram 2011. Stockholm: SD.

SD (2014). Vi väljer välfärd! Sverigedemokratiskt valmanifest - valet 2014. Stockholm: SD.

SD (2017). Manus för Jimmie Akessons tal i Almedalen. Stockholm: SD.

SD (2018a). Valmanifest: Sverigedemokraternas valmanifest 2018. Stockholm: SD.

SD (2018b). Talmanus för Jimmie Åkessons tal i Almedalen 2018. Stockholm: SD.

SD (2018c). “Tal till nationen - mitt Sverige 2028”, Youtube video, 13:51, 29 May, https://www.youtube.com/watch?v= ADf5eiv4bps.

Selåker, Johannes (2014). “Jimmie Åkessons valtal ord för ord”, Expressen, 15 September.

\section{Freedom Party of Austria (FPÖ)}

APA (2018). “FPÖ-Neujahrstreffen: "Bruno Kreisky würde heute HC Strache wählen”“, Die Presse, 13 January, https:// www.diepresse.com/5352970/fpo-neujahrstreffen-bruno-kreisky-wurde-heute-hc-strache-wahlen.

FPÖ (2008). Österreich im Wort: Auswahl und Zusammenfassung inhaltlicher Ziele der Freiheitlichen Partei Österreichs für die neue Legislaturperiode. Vienna: FPÖ.

FPÖ (2011). Parteiprogramm der Freiheitlichen Partei Österreichs (FPÖ). Vienna: FPÖ.

FPÖ (2013a). Liebe deine Nächsten: Für mich sind das unsere Österreicher. Vienna: FPÖ.

FPÖ (2013b). Handbuch freiheitlicher Politik: Ein Leitfaden für Führungsfunktionäre und Mandatsträger der Freiheitlichen Partei Österreichs. Vienna: FPÖ-Bildungsinstitut.

FPÖ (2017a). Österreicher verdienen Fairness: Freiheitliches Wahlprogramm zur Nationalrats-wahl 2017. Vienna: FPÖ.

FPÖ (2017b). Das Freiheitliche Wirtschaftsprogramm: Fairness. Freiheit. Fortschritt. Vienna: FPÖ-Bildungsinstitut.

FPÖ (2017c). “1. Mai 2017 - 'Wir sind die politische Kraft der Zukunft!”, Youtube video, 4:10, 1 May, https://www.youtube.

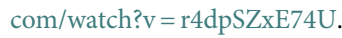

Cite this article: Schreurs, S. (2021). Those were the days: welfare nostalgia and the populist radical right in the Netherlands, Austria and Sweden. Journal of International and Comparative Social Policy 37: 128-141. https://doi.org/10.1017/ics.2020.30 